\title{
Methanolobus profundi sp. nov., a methylotrophic methanogen isolated from deep subsurface sediments in a natural gas field
}

Correspondence

Yoichi Kamagata

y.kamagata@aist.go.jp
Hanako Mochimaru, ${ }^{1,2}$ Hideyuki Tamaki, ${ }^{2}$ Satoshi Hanada,
Hiroyuki Imachi, ${ }^{2}$ Kohei Nakamura, ${ }^{2,4}$ Susumu Sakata ${ }^{1}$
and Yoichi Kamagata,

${ }^{1}$ Institute for Geo-Resources and Environment, National Institute of Advanced Industrial Science and Technology (AIST), Tsukuba, Ibaraki 305-8567, Japan

${ }^{2}$ Institute for Biological Resources and Functions, AIST, Tsukuba, Ibaraki 305-8566, Japan

${ }^{3}$ Subground Animalcule Retrieval Program, Extremobiosphere Research Center, Japan Agency for Marine-Earth Science and Technology, Yokosuka, Kanagawa 237-0061, Japan

${ }^{4}$ Faculty of Applied Biological Sciences, Gifu University, Yanagido, Gifu 501-1193, Japan

${ }^{5}$ Research Institute of Genome-based Biofactory, AIST, Sapporo, Hokkaido 062-8517, Japan

A mesophilic, methylotrophic methanogen, strain $\mathrm{MobM}^{\top}$, was isolated from a natural gas field in Japan. Strain MobM ${ }^{\top}$ grew on methanol and methylamines, but not on $\mathrm{H}_{2} / \mathrm{CO}_{2}$, formate, acetate or dimethyl sulfide. The cells were motile, irregular cocci (diameter, 0.9-1.2 $\mu \mathrm{m}$ ) and occurred singly, in pairs, as tetracocci or (occasionally) as aggregates. Strain $\mathrm{MobM}^{\top}$ grew at $9-37{ }^{\circ} \mathrm{C}$ (optimally at $30^{\circ} \mathrm{C}$ ) and at $\mathrm{pH} 6.1-7.8$ (optimally at $\mathrm{pH}$ 6.5). Sodium and magnesium were required for growth, at $0.1-1.0 \mathrm{M} \mathrm{Na}^{+}$(optimally at $0.35 \mathrm{M}$ ) and $10-400 \mathrm{mM} \mathrm{Mg}^{2+}$ (optimally at 15-25 mM). The $\mathrm{G}+\mathrm{C}$ content of the genomic DNA was $42.4 \mathrm{~mol} \%$. 16S rRNA gene sequencing revealed that the isolate is a member of the genus Methanolobus, but distinct from its closest neighbours, Methanolobus tindarius DSM $2278^{\top}$ (sequence similarity, 98.0\%) and Methanolobus vulcani DSM $3029^{\top}(98.1 \%)$. On the basis of phenotypic and phylogenetic features of $\mathrm{MobM}^{\top}$, it is clear that this strain represents a novel species of the genus Methanolobus, for which the name Methanolobus profundi sp. nov. is proposed. The type strain is $\operatorname{MobM}^{\top}\left(=\right.$ DSM $21213^{\top}=$ NBRC $\left.104158^{\top}\right)$.
The genus Methanolobus comprises coccoid, methylotrophic methanogens that grow optimally in media containing approximately $0.5 \mathrm{M} \mathrm{NaCl}$ (Boone et al., 2001; Table 1). To date, five species have been described; all have been found in various saline environments. Methanolobus bombayensis, Methanolobus oregonensis and Methanolobus taylorii can use dimethyl sulfide as a substrate for methanogenesis (Kadam et al., 1994; Liu et al., 1990; Oremland \& Boone, 1994), unlike the other two species, Methanolobus tindarius and Methanolobus vulcani (Konig \& Stetter, 1982; Kadam \& Boone, 1995). In this study, a slightly halophilic, methylotrophic methanogen, designated strain $\mathrm{MobM}^{\mathrm{T}}$, was isolated from subsurface sediments below $350 \mathrm{~m}$ in the Minami-Kanto Gas

The GenBank/EMBL/DDBJ accession number for the $16 \mathrm{~S}$ rRNA gene sequence of strain MobM ${ }^{\top}$ is $A B 370245$.

A supplementary figure showing the effects of variations in temperature and salinity on the specific growth rate of strain $\mathrm{MobM}^{\top}$ is available with the online version of this paper.
Field (Mobara, Chiba prefecture, Japan). This natural gas field is a dissolved-in-water type, and analyses of the stable carbon $\left({ }^{13} \mathrm{C} /{ }^{12} \mathrm{C}\right)$ and deuterium/hydrogen $(\mathrm{D} / \mathrm{H})$ isotopic composition of the methane and the ratio of methane to ethane and propane suggest that the methane is biogenic in origin (Igari \& Sakata, 1989). The reservoir rocks are turbidite sandstones deposited around $1 \mathrm{Ma}$ (million years ago) in a bathyal environment, being filled with ancient seawater (Sudo, 1967; Kunisue et al., 2002). The chemical composition of the formation water was conspicuously different from that of common seawater, i.e. it contained large amounts of iodine, bicarbonate and ammonia along with negligible amounts of sulfate. Culture-independent analysis of archaeal 16S rRNA gene sequences revealed that the methanogenic community residing in the formation water is diverse and includes close relatives of members of the genera Methanolobus, Methanohalophilus, Methanosaeta, Methanocalculus, Methanobacterium and Methanococcus (Mochimaru et al., 2007). Using a culture- 
Table 1. Differential characteristics for strain $\mathrm{MobM}^{\top}$ and species in the genus Methanolobus

Taxa: 1, MobM ${ }^{\mathrm{T}}$ (this study); 2, M. vulcani PL-12/M $\mathrm{M}^{\mathrm{T}}$ (Kadam \& Boone, 1995); 3, M. tindarius Tindari $3^{\mathrm{T}}$ (Konig \& Stetter, 1982); 4, M. taylorii GS-16 ${ }^{\mathrm{T}}$ (Oremland \& Boone, 1994); 5, M. oregonensis WAL1 ${ }^{\mathrm{T}}$ (Liu et al., 1990); 6, M. bombayensis B-1 ${ }^{\mathrm{T}}$ (Kadam et al., 1994). All strains were positive for utilization of methanol and methylamines. +, Positive result; -, negative result; ND, not determined.

\begin{tabular}{|c|c|c|c|c|c|c|}
\hline Characteristic & 1 & 2 & 3 & 4 & 5 & 6 \\
\hline Habitat & $\begin{array}{l}\text { Saline, deep } \\
\text { subsurface sand }\end{array}$ & Sea sediments & $\begin{array}{l}\text { Marine black } \\
\text { sediment }\end{array}$ & $\begin{array}{l}\text { Estuarine } \\
\text { sediments }\end{array}$ & $\begin{array}{l}\text { Saline, alkaline } \\
\text { aquifer }\end{array}$ & Sea sediments \\
\hline Flagella & + & - & + & - & - & - \\
\hline \multicolumn{7}{|l|}{$\begin{array}{l}\text { Optimum growth conditions } \\
\text { (range allowing growth): }\end{array}$} \\
\hline $\mathrm{pH}$ & $6.5(6.1-7.8)$ & $7.2(6.0-7.5)$ & $6.5(5.5-8.0)$ & $8.0(6.8-9.0)$ & $8.6(7.6-9.4)$ & $7.2(6.5-8.0)$ \\
\hline $\mathrm{Na}^{+}$concentration $(\mathrm{M})$ & $0.35(0.1-1.0)$ & $0.5(0.1-1.2)$ & $0.47(0.06-1.27)$ & $0.5(0.2-1.2)$ & $0.48(0.1-1.6)$ & $0.5(0.3-2.0)$ \\
\hline $\mathrm{Mg}^{2+}$ concentration $(\mathrm{mM})$ & $15-25(10-400)$ & $13(0.5-85)^{\star}$ & $\mathrm{ND}$ & $40(13-40)^{\star}$ & $40(13-220)^{\star}$ & $33(30-80)^{*}$ \\
\hline Utilization of dimethyl sulfide & - & - & - & + & + & + \\
\hline Growth factor(s) & - & Biotin & - & Biotin & Biotin, thiamine $\dagger$ & - \\
\hline $\begin{array}{l}\text { Stimulation by yeast extract } \\
\text { and/or peptone }\end{array}$ & 一‡ & + & - & + & + & + \\
\hline
\end{tabular}

${ }^{*}$ Data are from Kadam \& Boone (1995).

$\dagger$ Data are from Oremland \& Boone (1994).

‡Growth was inhibited slightly.

based method, we observed that methanol was converted to methane and that a Methanolobus-like methanogen dominated the primary enrichment culture (Mochimaru et al., 2007), indicating the presence of viable methylotrophic methanogens in the subsurface gas reservoir. A methanogen inhabiting the subsurface zone in the natural gas field was then isolated.

A sample for isolation purposes was obtained from a sand separator in the commercial gas/water-producing well at Mobara in June 2003. The sample, comprising sediment and formation water, came through the side-facing slit of the well at a depth of $347-795 \mathrm{~m}$. The temperature of the formation water was $22{ }^{\circ} \mathrm{C}$. The $\mathrm{pH}$ was 8.0 and the redox potential was $-232 \mathrm{mV}$.

To enrich for methanogens, saline mineral medium, as described by Sekiguchi et al. (2000), was used, but with the following slight modifications: the concentration of $\mathrm{MgCl}_{2} \cdot 6 \mathrm{H}_{2} \mathrm{O}$ was changed to $15 \mathrm{mM}$, and $350 \mathrm{mM} \mathrm{NaCl}$ was added. Enrichment was carried out at $25^{\circ} \mathrm{C}$ in $50 \mathrm{ml}$ serum vials containing approximately $10 \mathrm{ml}$ sediment sample and $20 \mathrm{ml}$ medium ( $\mathrm{pH} 7.0$ at $25{ }^{\circ} \mathrm{C}$ ) with $20 \mathrm{mM}$ methanol as the sole catabolic substrate, under an atmosphere of $\mathrm{N}_{2} / \mathrm{CO}_{2}(80: 20, \mathrm{v} / \mathrm{v})$.

Growth in the enrichments was confirmed by the formation of methane, and cultures showing methane production were transferred to fresh medium periodically.
The concentration of methane in the headspace of the bottle was measured at intervals of several weeks, using a gas chromatograph (GC-8A; Shimadzu) equipped with a thermal conductivity detector and a 60/80-mesh Unibeads column.

Isolation of strain $\mathrm{MobM}^{\mathrm{T}}$ was accomplished from repeated inoculations using plates containing $0.8 \%$ agar with $20 \mathrm{mM}$ methanol and vancomycin $\left(50 \mu \mathrm{g} \mathrm{ml}^{-1}\right)$ under an atmosphere of $\mathrm{N}_{2} / \mathrm{CO}_{2}(80: 20, \mathrm{v} / \mathrm{v})$. Visible colonies approximately $1 \mathrm{~mm}$ in diameter were produced after incubation at $30{ }^{\circ} \mathrm{C}$ for 10 days. Colonies on the surface of solid medium were circular with entire margins, shiny, convex and yellowish-white.

Cells in the late-exponential phase were observed by means of phase-contrast and epifluorescence microscopy, using an epifluorescence microscope (AX80; Olympus). Under phase-contrast microscopy, it was apparent that cells of the isolate were irregular cocci $0.9-1.2 \mu \mathrm{m}$ in diameter. Cells occurred singly, in pairs, as tetracocci or (occasionally) as aggregates (Fig. 1a). Under phase-contrast microscopy, a few cells showed motility. Transmission electron microscopy was performed with a Hitachi H7000 microscope (Nakamura et al., 2006). Negative staining indicated that cells of strain $\mathrm{MobM}^{\mathrm{T}}$ each have multiple flagella (Fig. 1b). In thin-section electron micrographs, neither an outer membrane nor a thick cell wall was observed (Fig. 1c). 


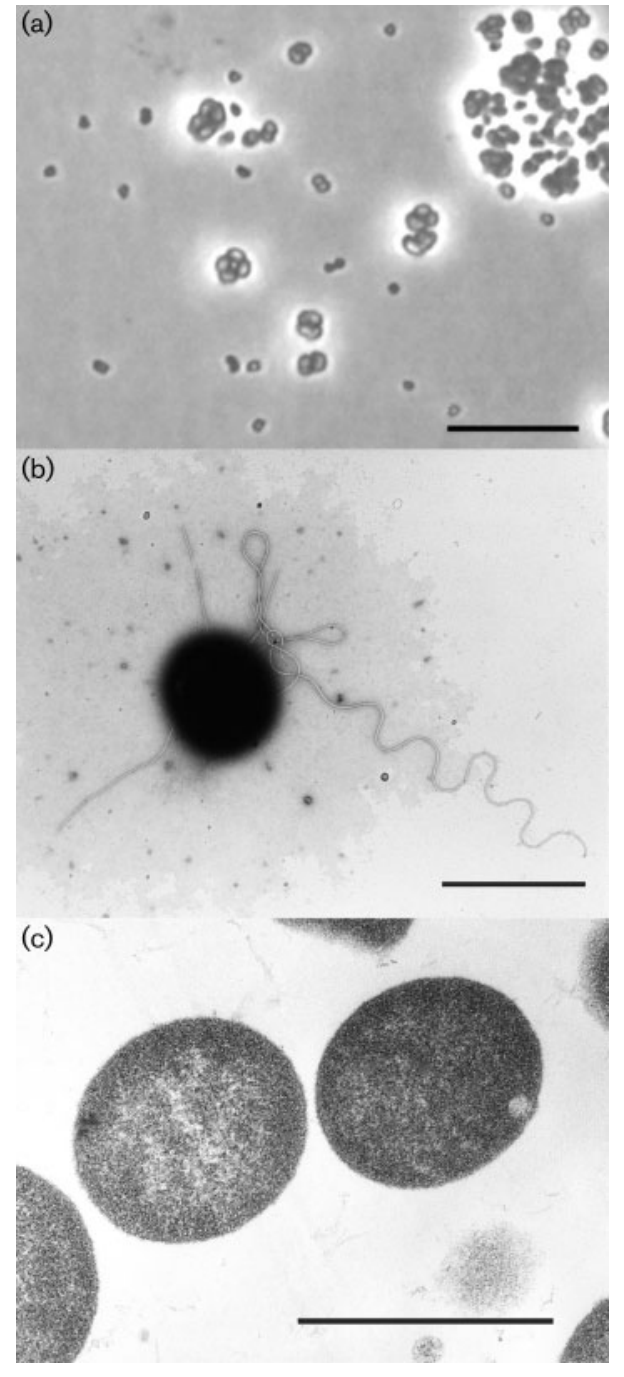

Fig. 1. Phase-contrast photomicrograph (a), electron micrograph of negatively stained cells (b) and electron micrograph of a thin section (c) of cells of strain $\mathrm{MobM}^{\top}$ in the late-exponential growth phase. Bars, $10 \mu \mathrm{m}(\mathrm{a}) ; 1 \mu \mathrm{m}$ (b, c).

The Gram reaction and tests of susceptibility to lysis by SDS were performed as described previously (Boone \& Whitman, 1988). The Gram reaction of strain $\mathrm{MobM}^{\mathrm{T}}$ was negative and cells lysed in a $0.01 \%(\mathrm{w} / \mathrm{v})$ SDS solution and in a hypotonic solution (distilled water).

The growth effects of variations in temperature, $\mathrm{pH}$ and concentrations of $\mathrm{Na}^{+}$and $\mathrm{Mg}^{2+}$ were tested in medium containing $20 \mathrm{mM}$ methanol under an atmosphere comprising $\mathrm{N}_{2} / \mathrm{CO}_{2}(80: 20, \mathrm{v} / \mathrm{v})$. Duplicate cultures (1\% inoculum) were incubated under each set of conditions and the $\mathrm{OD}_{600}$ was measured with an Ultrospec 500 pro (GE Healthcare) to ascertain growth rates. To evaluate the effect of temperature on growth, duplicate cultures were incubated at temperatures in the range $4-40{ }^{\circ} \mathrm{C}$. Strain $\mathrm{MobM}^{\mathrm{T}}$ grew at $9-37^{\circ} \mathrm{C}$ and $\mathrm{pH}$ 7.0, with an optimum growth temperature of $30{ }^{\circ} \mathrm{C}$ (Supplementary Fig. S1a, available in IJSEM Online). No growth occurred at 4 or $40{ }^{\circ} \mathrm{C}$ within 4 months. The isolate grew at $\mathrm{pH} 6.1-7.8$, with an optimum at $\mathrm{pH} 6.5$ (initial $\mathrm{pH}$ of culture medium). No growth was observed at $\mathrm{pH} 5.5$ or 8.1 within 2 months. Strain $\mathrm{MobM}^{\mathrm{T}}$ grew in the presence of $0.1-$ $1.0 \mathrm{M} \mathrm{Na}^{+}$, the optimum concentration being $0.35 \mathrm{M}$ (Supplementary Fig. S1b). It also grew in the presence of 10-400 $\mathrm{mM} \mathrm{Mg}^{2+}$, the optimum concentration being 15$25 \mathrm{mM}$. No growth was observed in medium supplemented with 0 or $1.5 \mathrm{M} \mathrm{Na}^{+}$or with 5 or $500 \mathrm{mM} \mathrm{Mg}{ }^{2+}$ within 2 months incubation. The doubling time for the culture on methanol under the optimum conditions was $5 \mathrm{~h}$.

Strain MobM $^{\mathrm{T}}$ used methanol $(20 \mathrm{mM})$, monomethylamine $(20 \mathrm{mM})$, dimethylamine $(20 \mathrm{mM})$ and trimethylamine $(20 \mathrm{mM})$ as energy and carbon sources. Growth and methane formation were not observed on the following substrates: $\mathrm{H}_{2} / \mathrm{CO}_{2} \quad(80: 20, \mathrm{v} / \mathrm{v} ; 100 \mathrm{kPa})$, acetate $(20 \mathrm{mM})$, formate $(20 \mathrm{mM})$, ethanol $(20 \mathrm{mM})$ and dimethyl sulfide $(5 \mathrm{mM})$. The addition of yeast extract $\left(2 \mathrm{~g} \mathrm{l}^{-1}\right)$ or peptone $\left(2 \mathrm{~g} \mathrm{l}^{-1}\right)$ inhibited growth slightly. Acetate $(5 \mathrm{mM})$ did not stimulate growth in the presence of methanol. The isolate did not require any vitamins and did not require tungsten or selenium.

The sensitivities of strain MobM $^{\mathrm{T}}$ to antibiotics such as ampicillin, penicillin G, vancomycin, kanamycin and tetracycline (each at a final concentration of $100 \mu \mathrm{g} \mathrm{ml}^{-1}$ ) were tested at $30{ }^{\circ} \mathrm{C}\left(\mathrm{pH}\right.$ 7.0). Strain $\mathrm{MobM}^{\mathrm{T}}$ was resistant to all five antibiotics, but growth in the presence of tetracycline was extremely slow.

The $\mathrm{G}+\mathrm{C}$ content of the genomic DNA was determined by means of HPLC (LC-10A; Shimadzu) with a UV detector (Kamagata \& Mikami, 1991): the value obtained was $42.4 \mathrm{~mol} \%$.

The 16S rRNA gene of strain MobM ${ }^{\mathrm{T}}$ was amplified using a PCR with a forward primer (Escherichia coli positions 8-27; Kamagata et al., 1997) and a slightly modified version of universal primer 1490R (Weisburg et al., 1991) and sequenced as described previously (Mochimaru et al., 2007). The phylogenetic tree obtained by using almostcomplete 16S rRNA gene sequences (1405 bp) indicated that strain MobM ${ }^{\mathrm{T}}$ was closely related to M. tindarius DSM $2278^{\mathrm{T}}$ and M. vulcani DSM $3029^{\mathrm{T}}$, having sequence similarity of 98.0 and $98.1 \%$, respectively (Table 1; Fig. 2).

Strain MobM $^{\mathrm{T}}$ and its closest phylogenetic relatives, $M$. tindarius and M. vulcani, are all methylotrophic methanogens unable to use dimethyl sulfide as a catabolic substrate (Table 1). Although these three methanogens have similar cell sizes and $\mathrm{pH}$ and $\mathrm{NaCl}$ requirements, there are significant differences among them. The genomic $\mathrm{G}+\mathrm{C}$ content of $\mathrm{MobM}^{\mathrm{T}}$ clearly differs from those of $M$. tindarius and M. vulcani. The maximum growth temperature is the most remarkable feature distinguishing strain $\mathrm{MobM}^{\mathrm{T}}$ from the two related species: MobM ${ }^{\mathrm{T}}$ cannot tolerate temperatures above $40{ }^{\circ} \mathrm{C}$ (Supplementary Fig. 


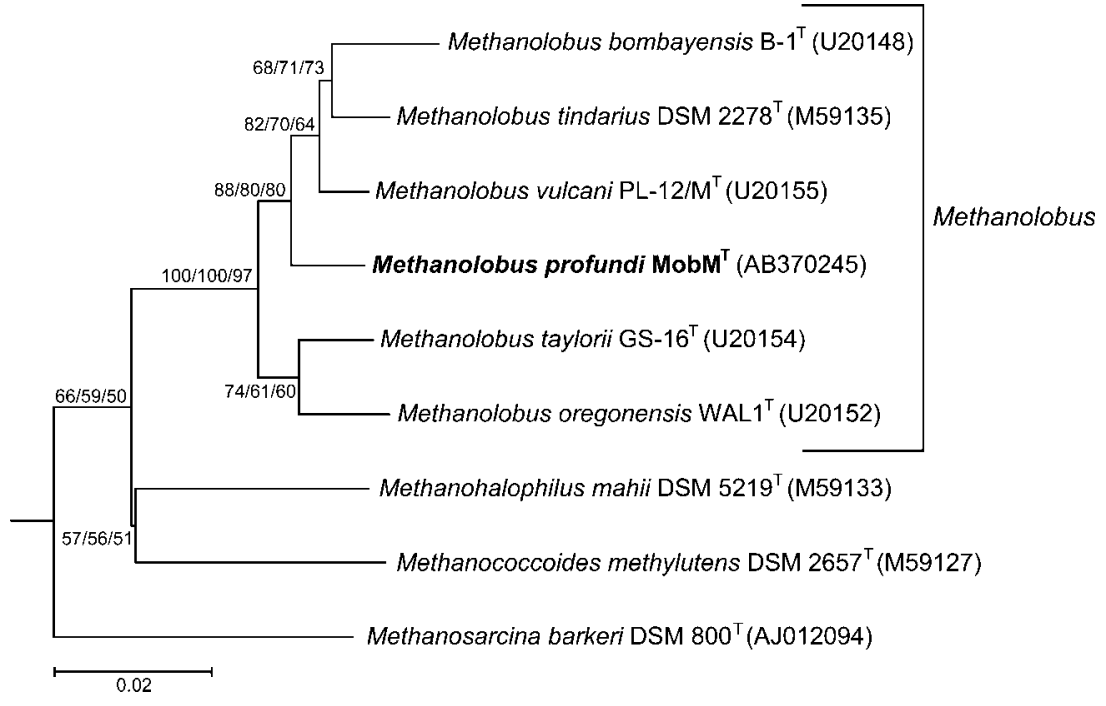

Fig. 2. Phylogenetic tree based on $16 \mathrm{~S}$ rRNA gene sequences, showing the position of strain MobM $^{\top}$ with respect to members of the genus Methanolobus and related taxa. The tree was constructed by using the neighbour-joining method (Saitou \& Nei, 1987) with the CLUSTAL_X software package (Thompson et al., 1997). The tree topologies were evaluated by bootstrap analysis (based on 1000 replicates) with the neighbour-joining/maximum-parsimony/ maximum-likelihood methods, using the PAUP* package (Swofford, 2003). Methanococcus aeolicus was used as an outgroup (not shown). Bar, 2 substitutions per $100 \mathrm{nt}$.

S1a, available in IJSEM Online), whereas M. tindarius and M. vulcani are able to grow at temperatures up to $45^{\circ} \mathrm{C}$. The other distinctive feature of $\mathrm{MobM}^{\mathrm{T}}$ was that the optimum $\mathrm{NaCl}$ concentration $(0.35 \mathrm{M})$ was slightly lower (Supplementary Fig. S1b) than those $(0.48-0.5 \mathrm{M})$ of all other known species within the genus Methanolobus. This may reflect the fact that the in situ $\mathrm{NaCl}$ concentration of the gas-associated ancient seawater $(0.2 \mathrm{M})$ in which the isolate resides is slightly lower than that in seawater (0.5 M) (Mochimaru et al., 2007).

On the basis of phenotypic and phylogenetic data, therefore, strain MobM ${ }^{\mathrm{T}}$ represents a novel species of the genus Methanolobus, for which the name Methanolobus profundi sp. nov. is proposed.

\section{Description of Methanolobus profundi sp. nov.}

Methanolobus profundi sp. nov. (pro.fun'di. L. gen. n. profundi of an abyss).

Cells are irregular, motile cocci (diameter, 0.9-1.2 $\mu \mathrm{m}$ ) and occur singly, in pairs, in tetracocci and in aggregates. Strictly anaerobic. Gram-negative. Lysed by $0.01 \%(w / v)$ SDS and hypotonic solution (distilled water). Colonies on the surface of solid medium are circular with entire margins, shiny, convex and yellowish-white. Methane is produced from methanol, monomethylamine, dimethylamine and trimethylamine, but not from $\mathrm{H}_{2} / \mathrm{CO}_{2}$, formate, acetate, ethanol or dimethyl sulfide. Growth occurs between 9 and $37{ }^{\circ} \mathrm{C}$, with an optimum at $30{ }^{\circ} \mathrm{C}$. The $\mathrm{pH}$ range for growth is 6.1-7.8 and the optimum is $\mathrm{pH} 6.5$. Sodium and magnesium are required for growth: the ranges are $0.1-1.0 \mathrm{M} \mathrm{Na}^{+}$(optimum, $0.35 \mathrm{M}$ ) and 10 $400 \mathrm{mM} \mathrm{Mg}^{2+}$ (optimum, 15-25 mM). Vitamins, tungsten and selenium are not required. Resistant to ampicillin, penicillin $G$, vancomycin, kanamycin and tetracycline at concentrations of at least $100 \mu \mathrm{g} \mathrm{ml}^{-1}$. The DNA G $+\mathrm{C}$ content of strain $\mathrm{MobM}^{\mathrm{T}}$ is $42.4 \mathrm{~mol} \%$.
The type strain, MobM $^{\mathrm{T}} \quad\left(=\mathrm{DSM} \quad 21213^{\mathrm{T}}=\mathrm{NBRC}\right.$ $104158^{\mathrm{T}}$ ), was isolated in Mobara, Japan, from deep subsurface sediments from a natural gas field filled with ancient seawater.

\section{Acknowledgements}

We gratefully acknowledge the late Yoshiyuki Tazaki and Hiroshi Iwamoto (Kanto Natural Gas Development Co., Ltd) for kindly providing the samples and information about gas wells. We are grateful to Toshihiro Hoaki (Technology Center, Taisei Corporation) for his kind help during sample collection. We also thank Xian-Ying Meng and Mizuho Muramatsu (AIST) for electron microscopy and determination of DNA G+C contents, respectively. K.N. is supported by a grant from the JSPS Research Fellowships for Young Scientists.

\section{References}

Boone, D. R. \& Whitman, W. B. (1988). Proposal of minimal standards for describing new taxa of methanogenic bacteria. Int J Syst Bacteriol 38, 212-219.

Boone, D. R., Whitman, W. B. \& Koga, Y. (2001). Order III. Methanosarcinales ord. nov. In Bergey's Manual of Systematic Bacteriology, 2nd edn, vol. 1, pp. 268-294. Edited by D. R. Boone, R. W. Castenholz \& G. M. Garrity. New York: Springer.

Igari, S. I. \& Sakata, S. (1989). Origin of natural gas of dissolved-inwater type in Japan inferred from chemical and isotopic compositions: occurrence of dissolved gas of thermogenic origin. Geochem $J$ 23, 139-142.

Kadam, P. C. \& Boone, D. R. (1995). Physiological characterization and emended description of Methanolobus vulcani. Int J Syst Bacteriol 45, 400-402.

Kadam, P. C., Ranade, D. R., Mandelco, L. \& Boone, D. R. (1994). Isolation and characterization of Methanolobus bombayensis sp. nov., a methylotrophic methanogen that requires high concentrations of divalent cations. Int J Syst Bacteriol 44, 603-607.

Kamagata, Y. \& Mikami, E. (1991). Isolation and characterization of a novel thermophilic Methanosaeta strain. Int J Syst Bacteriol 41, 191196. 
Kamagata, Y., Fulthorpe, R. R., Tamura, K., Takami, H., Forney, L. J. \& Tiedje, J. M. (1997). Pristine environments harbor a new group of oligotrophic 2,4-dichlorophenoxyacetic acid-degrading bacteria. Appl Environ Microbiol 63, 2266-2272.

Konig, H. \& Stetter, K. O. (1982). Isolation and characterization of Methanolobus tindarius, sp. nov., a coccoid methanogen growing only on methanol and methylamines. Zentralbl Bakteriol Parasitenkd Infektionskr Hyg Abt 1 Orig C3, 478-490.

Kunisue, S., Mita, I. \& Waki, F. (2002). Relationship between subsurface geology and productivity of natural gas and iodine in the Mobara gas field, Boso Peninsula, central Japan. J Jpn Assoc Pet Tech 67, 83-96.

Liu, Y., Boone, D. R. \& Choy, C. (1990). Methanohalophilus oregonense sp. nov., a methylotrophic methanogen from an alkaline, saline aquifer. Int J Syst Bacteriol 40, 111-116.

Mochimaru, H., Uchiyama, H., Yoshioka, H., Imachi, H., Hoaki, T., Tamaki, H., Nakamura, K., Sekiguchi, Y. \& Kamagata, Y. (2007). Methanogen diversity in deep subsurface gas-associated water at the Minami-Kanto gas field in Japan. Geomicrobiol J 24, 93-100.

Nakamura, K., Terada, T., Sekiguchi, Y., Shinzato, N., Meng, X. Y., Enoki, M. \& Kamagata, Y. (2006). Application of pseudomurein endoisopeptidase to fluorescence in situ hybridization of methano- gens within the family Methanobacteriaceae. Appl Environ Microbiol 72, 6907-6913.

Oremland, R. S. \& Boone, D. R. (1994). Methanolobus taylorii sp. nov., a new methylotrophic, estuarine methanogen. Int J Syst Bacteriol 44, 573-575.

Saitou, N. \& Nei, M. (1987). The neighbor-joining method: a new method for reconstructing phylogenetic trees. Mol Biol Evol 4, 406425.

Sekiguchi, Y., Kamagata, Y., Nakamura, K., Ohashi, A. \& Harada, H. (2000). Syntrophothermus lipocalidus gen. nov., sp. nov., a novel thermophilic, syntrophic, fatty-acid-oxidizing anaerobe which utilizes isobutyrate. Int J Syst Evol Microbiol 50, 771-779.

Sudo, Y. (1967). Geochemical study of brine from oil and gas fields in Japan. J Jpn Assoc Pet Technol (Tokyo) 32, 286-296.

Swofford, D. L. (2003). PAUP ${ }^{\star}$ : Phylogenetic analysis using parsimony ( ${ }^{*}$ and other methods), version 4. Sunderland, MA: Sinauer Associates.

Thompson, J. D., Gibson, T. J., Plewniak, F., Jeanmougin, F. \& Higgins, D. G. (1997). The CLUSTAL_X windows interface: flexible strategies for multiple sequence alignment aided by quality analysis tools. Nucleic Acids Res 25, 4876-4882.

Weisburg, W. G., Barns, S. M., Pelletier, D. A. \& Lane, D. J. (1991). $16 \mathrm{~S}$ ribosomal DNA amplification for phylogenetic study. J Bacteriol 173, 697-703. 